Оригинални научни рад

Gordana B. Kovaček Stanić, Ph.D., Full Professor

University of Novi Sad

Faculty of Law Novi Sad

G.KovacekStanic@pf.uns.ac.rs

Sandra O. Samardžić, Assistant with Ph.D.

University of Novi Sad

Faculty of Law Novi Sad

Sandra.Samardzic@pf.uns.ac.rs

\title{
MARRIAGE IN SERBIAN LAW AND IN COMPARATIVE PERSPECTIVE
}

\begin{abstract}
According to the Serbian Family Act marriage is cohabitation between two persons of the opposite sex governed by the law. The same act, prescribes substantial and formal requirements for valid marriage. This paper aims to present a review of these requirements in domestic and comparative law as well. It analyzes each condition separately, giving an overview of their historical development and the way they are regulated today in different legal systems. According to domestic law, substantial requirements are the following: opposite gender, expression of will to get married, cohabitation and lack of marriage impediments. However, there is a tendency in the contemporary family law to reduce marriage impediments, which leads to the liberalization and facilitation of marriage formation. Since marriage is very often concluded in religious form, article also gives an overview of the ecclesiastical rules concerning marriage. Finally, it analyzes and compares statistical data concerning number of concluded marriages and divorces in Serbia thirty years ago and in present time.
\end{abstract}

Keywords: marriage, marriage requirements, marriage form, marriage impediments, divorce. 


\section{INTRODUCTION}

The Serbian Family Act $^{1}$ (hereinafter: Family Act) defines marriage as cohabitation between a man and a woman governed by the law (Art 3/1). According to this definition, the basic elements of marriage are: cohabitation between two persons of the opposite sex, monogamous cohabitation (cohabitation of one woman and one man), which is governed by the law. Cohabitation is a complex relationship, which implies different relations between spouses, based on love, including intimate relationship, respect, support, economic relationship, etc. If marriage is entered into in order to achieve a goal other than the intent to form cohabitation (e.g. the acquisition of citizenship, work permit, domicile, habitual residence, inheritance, housing rights or other property rights), it is to be considered as fictitious marriage that is not valid (Art. 16 of Family Act).

There is a tendency in the contemporary family law to reduce marriage impediments, which leads to the liberalization and facilitation of marriage formation. According to Family Act, substantial requirements are the following: opposite gender, expression of will to get married, cohabitation and lack of marriage impediments (inability to reason, existing marriage, minority, kinship by blood or adoption, affinity, lack of free will, guardianship) (Art. 15-24).

\section{MARRIAGE REQUIREMENTS}

The marriage may only be solemnized between two persons of the opposite sexes, a woman and a man. In Serbia, there is no act that governs the same sex union, cohabitation or marriage, nor the act that governs legal status of the persons who changed their sex (transsexuals). Thus, the main condition on the validity of marriage is the opposite sex of the parties. In most cases, the opposite sex condition is unquestionable. The registrar determines the sex of the future spouses through the birth certificate, as well as through visual facts. However, this condition can be contentious in exceptional situations, mainly because of the biological characteristics of a specific person.

In modern times, the phenomenon of transsexualism or sex change has an impact on marriage conclusion. ${ }^{2}$ Of great importance was the decision of the Constitutional Court of Serbia from 2010, which ordered the municipal authorities to decide on the application for registration of the individual's gender change. In this case, the applicant who has submitted the constitutional complaint was a person who had sex reassignment surgery. He was not able to change the gender in the

${ }^{1}$ Porodični zakon (Family Act), Official Journal of the RS, No 18/05.

${ }^{2}$ More in: Marija Draškić, Transsexual persons: Right to marry in the countries of former Yugoslavia, Marriage and Quasi-marital Relationships in Central and Eastern Europe, 2006, 253. 
register, as the municipal authority declared itself incompetent, citing the Act on Registers of Serbia, which does not provide such a possibility. The Constitutional Court assessed that in this case the principle of protection of human dignity and the free development of personality have to prevail. Therefore, the Court ordered the competent municipal authority to decide on this request for registration of the individual's gender change. ${ }^{3}$

Afterwards, the Act on Registers of Serbia was amended. The article, which regulates sex changes, is added. The fact on sex changes should be registered in the register on the decision of the municipal administrative organ, which make a decision on the ground of medical certificate. ${ }^{4}$

Viewed comparatively, states that have laws regulating this matter are, for example: Sweden, Germany, Italy, the Netherlands, Turkey. ${ }^{5}$ Special laws distinguish two types of assumptions for sex change: medical and legal. Medical assumptions are: „real life" test (behavior of a person as a member of the opposite sex for a certain period of time - this condition is required in Sweden and Germany), sterility (required in Sweden, Germany and the Netherlands) and surgery (explicit condition only in Germany). Surgical intervention refers to the intervention on the external organs, since the surgery on the internal genitalia (sterilization) has to be conducted before intervention on the external organs. It is interesting to note that surgery on the external genitalia is not a conditio sine qua non of a sex change in all countries. At first sight, sex change is related to surgery on the external genitalia. However, as can be seen, this medical condition is not a universal condition for sex change. Legal conditions refer to whether only name change is allowed or the right to change sex as well. Furthermore, these conditions can prescribe a minimum age for changing civil status, a condition of citizenship, and a certain marital status. Germany has two solutions: a „small solution" (name change) in cases where no surgery is performed and a „big solution“ (sex change and name change). The minimum age for changing civil status is prescribed only in Sweden - 18 years (previously, such a change was only possible at the age of 25). In Germany, this condition was abolished as unconstitutional. Citizenship is a

${ }^{3}$ See the decision of the Constitutional Court: UŽ-3238/2011 http://www.ustavni.sud.rs/ Storage/Global/Documents/UstavneZalbe/\%D0\%A3\%D0\%B6-3238-2011.pdf, 10.12.2019.

${ }^{4}$ Bill on Amendments and Supplements to the Act on Registers of Serbia, Official Journal of the RS, No 47/2018 (Art. 45b).

${ }^{5}$ Sweden - Gender Recognition Act (1972:119); Germany - Act on the change of first name and determination of gender identity in special cases (Transsexuals Act - TSG) 1980, (Gesetz über die Änderung der Vornamen und die Feststellung der Geschlechtszugehörigkeit in besonderen Fällen vom 10. September 1980 (Transsexuellengesetz - TSG)); Italy - Law no. 164/1982, Rules Concerning the Rectification of Sex-Attribution, Legge 14 aprile 1982, n. 164. Norme in materia di rettificazione di attribuzione di sesso; Netherlands - Code Civile art. 28 - Court order to change the description of gender on the birth certificate; Turkey - Law amending the relevant provisions of the 1988 Civil Code. (Draskic, 2006) 
necessary condition in Sweden and Germany. Regarding marital status, there are three solutions: a person who wants to change sex should not be married (Sweden, Netherlands, Germany); marriage ends automatically on the date of the legality of the decision of sex change (Turkey) and sex change is a ground for the divorce (Italy). The effect of changing sex has an effect ex nunc, from the moment of registration, which means that it has no retroactive effect (Netherlands, Germany and Italy). Only new gender is entered in the birth certificate, the exception being the declaratory decision in relation to kinship. Kinship remains as it was before the change, the legal relationships of transsexual people with parents and offspring remain intact. ${ }^{6}$

Another condition for formation of marriage is a will of future spouses. The will of future spouses is tackled through the requirement of expression of will, then marriage impediments - incapability of reasoning and lack of free will, while the will is also important for the requirement of marriage to be concluded with the intent to form cohabitation. The person who expresses the will shall be capable of reasoning; the will shall be freely expressed, without deficiencies in will, e.g. force and misconception.

In Serbian family law theory, the condition, which refers to the affirmation of will of the future spouses, is classified as conditions for concluding the marriage. Given that marriage has a dual legal nature, contractual and institutional, the condition of expressed will could be considered as the element of form, similar to a consensual form of contract conclusion. For instance, according to the Serbian Orthodox Church Marriage Rules ${ }^{7}$ the conclusion of marriage without the expressed free will of the bride and the groom represents an irremovable obstacle due to lack of form (para. 33/2).

According to Family Act, marriage may be concluded only on the grounds of free consent of future spouses (art. 3/2). The consent in fact is an affirmative statement of will. In the family law theory, it is considered that the will of future spouses must be expressed seriously, clearly, without terms and conditions, simultaneously or successively, one after another. The rule is that the will is expressed verbally and personally. However, there can be exceptions in the cases where a person is not able to verbally declare their will (for example, a deaf-mute persons), when it is allowed to be done in writing or in the sign language with the help of an

\footnotetext{
${ }^{6}$ See more in: Marija Draškić, Транссексуалит̄ет̄ и брак (Transsexuality and marriage), Nomos, Beograd, 1994.

${ }^{7}$ Bračna pravila Srpske pravoslavne crkve, II dopunjeno i ispravljeno izdanje Svetog arhijerejskog sinoda, Beograd 1994. štampano izdanje: Bračna pravila srpske pravoslavne crkve objavljena su prvi put u „Glasniku“, Službenom listu Srpske pravoslavne patrijaršije od 7. septembra (25. avgusta) 1933. godine. (Marital Rules of Serbian Orthodox Church, (The Marital Rules of Serbian Orthodox Church were published for the first time in Official Journal Of The Serbian Orthodox Patriarchy, September 7 (August 25), 1933, No. 34-35. II Completed and Corrected Edition of the Holy Archiery Synod, Belgrade 1994.)
} 
interpreter. Giving informed consent with the help of an interpreter is also a solution when a person who does not know the language of the competent authority before which the marriage is being concluded enters into marriage. Exceptionally, the will does not have to be expressed in person, but by a proxy.

\subsection{Marriage impediments}

In Serbian family law marriage impediments are: inability to reason, existing marriage, minority, kinship by blood or adoption, affinity, lack of free will and guardianship.

Inability to reason, as one of the marriage impediments, may be the result of a mental illness or mental disorder, mental retardation or other circumstances, e.g. the person being under the influence of alcohol, narcotics or any affective state, which leads to a temporary mental inability. In the law theory, mental inability refers to the inability of a person to understand the significance and consequences of the conclusion of the legal act. The Family Act determines inability to reason as an impediment to marriage ability, leaving out the reason that has led to the inability (mental illness) and thus giving primacy to the consequence that ensued. Earlier on, the mental illness is regarded as the marriage impediment. According to the Serbian Civil Code of 1844 marriage could not be concluded between the "crazy and frantic", Para 69/d.

Viewed comparatively, the 1998 family law reform of Switzerland, for example, abandoned the condition of mental health for marriage. The reason for abandonment of this condition is its eugenic connotation. However, permanent and temporary mental incapacity remained as reasons for annulment of marriage. ${ }^{8}$ Some laws explicitly stipulate that mentally ill persons cannot marry. Thus, for example, in Russia, persons who have been deprived of legal capacity because of a mental disorder cannot conclude marriage. ${ }^{9}$ In the Netherlands, persons who, due to a serious mental illness do not have the ability to understand the consequences of marriage cannot marry. ${ }^{10}$

According to English law system, marriage is null and void if at the time of the marriage, one of the spouses suffered from a mental disorder of such a nature and extent that made that person incapable for marriage. ${ }^{11}$ Greek law requires that both parties have legal capacity. Persons who have a court injunction to conclude

${ }^{8}$ Olivier Guillod, A New Divorce Law for the New Millennium, The International Survey of Family Law, A. Bainham (ed.), 2000, 358-359.

${ }^{9}$ Art. 14 of Family Act 1995, Семейный кодекс и брачный договор, Социальная защиита, выпуск 5/1996.

${ }^{10}$ Wendy M. Schrama, Registered Partnership in the Netherlands, International Journal of Law, Policy and the Family 13, (1999), 315-327, (see Dutch Civil Code: Book 1, Title 1.5, art. 1:32).

${ }^{11}$ Matrimonial Causes Act 1973, s 12, Caroline Hamilton, Kate Standley, Family Law in England and Wales, Family Law in Europe, 1995, 70. 
treaties (due to their inability to take care of themselves or their property due to permanent mental or physical disabilities, especially blind, deaf or deaf- mute persons) may marry, if their supervisor or court agrees. On the other hand, persons having the same prohibition, but due to committed criminal offense (when this prohibition occurs ipso iure) may legally conclude a marriage. ${ }^{12}$

Although it is universally accepted that persons who do not have the necessary psychic abilities cannot marry, there is the other side of the coin. Namely, in American case law the issue of violation of the right to marry has been raised, more precisely, whether the individual's right to marry is violated in case of people with physical or mental disabilities. ${ }^{13}$ Similarly, in Finland, the institution of marriage is considered a more individual and less exclusive institution, so the persons under guardianship can marry if the guardian agrees, and if the consent is denied, the consent can be given by a court. ${ }^{14}$ The solution of the Croatian Family Act of 2015 is also interesting to mention. According to this Act, a person deprived of legal capacity in making statements relating to personal issues may marry with the approval of a guardian. (Art. 26/2). ${ }^{15}$

An existing marriage is another marriage impediment, which derives from the monogamy principle. An existing marriage is a temporary impediment, so if the marriage is dissolved, either because of death, or because of divorce or annulment, the ex-spouses can conclude a new marriage without any obstacle (art. 17 of Family Act). According to the regulations that were in force in Serbia before World War II, a previously concluded marriage represented the marriage obstacle, but in a more strict way than today. According to the Serbian Orthodox Church Marriage Rules, the existence of a certain number of previously concluded marriages constituted obstacle, as well. Thus, four previous marriage constituted an irremovable obstacle, and three previous marriages constituted a removable obstacle, meaning that the fourth marriage could be concluded only with permission, while any further marriages were not allowed, Para 12/8, 13/7. It could be said that under these regulations the successive polygamy was also taken into account, which has no legal significance today. In addition, according to the Serbian Orthodox Church Marriage Rules a person who divorced twice because of his fault could no longer conclude a new marriage, Para 114.

The next important requirement for marriage is the capacity to get married. In the Serbian law, marriage impediment is minority. The marriage age is 18 , equally for both men and women, Art 23 Family Act. It corresponds to the age when the

${ }^{12}$ Efie Kounougeri-Manoledaki, Family Law in Greece, Family Law in Europe, 1995, 201-202.

${ }^{13}$ Mary Ann Glendon, The Transformation of Family Law, University of Chicago Press, 1996, 38.

${ }^{14}$ David Bradley, Politics, Culture and Family Law in Finland: Comparative Approaches to the Institution of Marriage, International Journal of Law, Policy and the Family 12, (1998), 288306. (1987 amendments, Marriage Act).

${ }^{15}$ Croatian Family Law Act, Official Gazette No. 103/15. This right was introduced in 2003. 
legal capacity is obtained. However, in justified cases, the Court may allow marriage of a minor, who has reached the age of 16 and who has achieved physical and mental maturity necessary to exercise marital rights and duties. The granting of permission represents the way to remove the effect of marriage impediment (dispensation). The Marriage Act from 1946 introduced the age of 18 as marriageable age in the Serbian law. Historically speaking, according to the Serbian Civil Code 1844 women have gained marriage maturity at age 15, and men at 17, earlier than the age of majority (age of majority was acquired at the age of 21). Under the law which was in force at that time in Vojvodina, marriage could be concluded between men who were over 18, and women who were 16 years old, but the Minister of Justice could give a dispensation for this setback, Para 7-9 Marriage Act. ${ }^{16}$

Viewed comparatively, in most jurisdictions marriageable age coincides with the age of majority. However, in some states persons can marry before or after the age of majority. In most countries, the age of 18 is the threshold of full legal capacity and thus capacity to marry, but many Western European countries introduced this age limit relatively recently - in the 1970s. For example, the age of 18 in France and Germany was introduced in 1974, in the United Kingdom in 1969 (before that, the limit was 21 years old). ${ }^{17}$ In 1996, Switzerland also set up the age of 18 as marriage age for women and men. Before this change, the limit for men was 20 and for a woman 18. Under exceptional circumstances and with permission marriage was possible for men at the age of 18 and for women at the age of $17 . .^{18}$

In both, Central and Eastern European countries, the marriageable age and the legal age of capacity is 18 and is the same for women and men (Russia, Bulgaria, Czech Republic, Hungary, Russia, Slovakia, Macedonia, Croatia, Slovenia, Bosnia and Herzegovina).

According to Albanian Family Code, the legal minimum age for marriage is 18 , but the same article prescribes that "the court in the location where the marriage is to be concluded may, for sufficient reasons, allow marriage prior to this age"19. In such case, no minimum age is defined. Even though, the full legal capacity is attained at the age of 18 , if a girl conclude marriage before the age of 18 , she automatically attains legal capacity. Similar situation is in Poland where majority, understood as full capacity for legal actions, is attained at 18 . However, there is a possibility for women above 16, because of important reasons and with a court permission to conclude marriage. This marriage constitutes full legal capacity for the spouses.

\footnotetext{
${ }^{16}$ Zvonimir Piškulić, Imre Đerđ, Osnovi privatnog prava u Vojvodini (Foundations of Private Law in Vojvodina), Geca Kon, Belgrade, 1924, 222-223.

${ }^{17}$ M.A. Glendon, 38.

${ }^{18}$ Olivier Guillod, Choosing its Own Way or Following Others?, The International Survey of Family Law, A. Bainham (ed.), 1995, 490.

${ }^{19}$ See Article 7 of Family Code of Albania, Law Number 9062 Adopted May 8, 2003.
} 
The Serbian law does not allow marriage between blood relatives in a direct line without exception, and between blood relatives up to the fourth degree in the collateral line, or to be more precise, between all the relatives up to the third degree (brother and sisters, half-brother and half-sisters, uncle and niece, aunt and nephew), and in the fourth degree between cousins (the children of brothers and sisters and children of half-brothers and half-sisters) ${ }^{20}$ From a historical perspective, at the territory of Serbia kinship constituted an obstacle for concluding marriage in a much wider way than today. According to Serbian Orthodox Church, relatives were not able to get married, and the prohibited degrees were prescribed by the church rules (Para. 69/j). According to Marital Rules of Serbian Orthodox Church, irremovable obstacles for concluding marriage are as follows: blood relations in direct line, and among relatives in collateral line, to the fourth degree, and from the fifth to the seventh degree was a removable obstacle (Para. 12/2-6).

In the case of blood relatives, in contemporary Serbian law dispensation is not possible. According to the previous Principle Act on Marriage 1946, there was a possibility of dispensations for fourth-degree relatives (the children of brothers and sisters and the children of half-brothers and half-sisters), on condition that it is not in collision with the public perception. Today, according to Family Act relation based on adoption shall constitute an obstacle for concluding marriage in the same manner as blood relation (art. 20).

Comparatively, it can be said that the second degree of kinship (siblings) is universally accepted as an irremovable obstacle, except in Sweden, where halfbrothers and half-sisters can obtain a permission from government or from a government-designated body. ${ }^{21}$ The intention is for dispensation to be given only if there are particular reasons, inter alia, for parties to be raised in different families, and permission is given only in a small number of cases. ${ }^{22}$ In Switzerland, marriage between siblings is prohibited. ${ }^{23}$ Most of the societies across the world prescribe impediment on marriages between people in third degree of collateral line (uncle- niece, aunt- nephew), but in some laws there is a possibility of dispensation, for example in France where the president of the Republic may give a permission for conclusion of marriage between abovementioned people. In Germany, the restriction exists between all relatives in a direct line, and between siblings and half-siblings, that is between relatives in second degree of collateral line. ${ }^{24}$ The same regulation exists in the Netherlands.

${ }^{20}$ See art. 19 of Family Act.

${ }^{21}$ Chapter 2, sec. 3 Marriage Act (SFS 1987:230, with amendments 1988:1452), https://www. riksdagen.se/sv/dokument-lagar/dokument/svensk-forfattningssamling/aktenskapsbalk-1987230 sfs-1987-230, 22.12.2019.

${ }^{22}$ Lars Tottie, Family Law, An Introduction to Swedish Law, (ed. Stig Strömholm), Springer, Dordrech, 1981, 203.

${ }^{23}$ O. Guillod, 358 .

${ }^{24}$ L. Tottie, 168. 
In the UK, a man cannot marry with immediate ascendants and descendants, a sister, an aunt or a niece. The same rules apply to a female in relation to male relatives. ${ }^{25}$ So the prohibition exists between relatives in a direct line and between relatives in collateral line in third degree. In Russia, by the 1995 Code, kinship as an impediment is prescribed in a direct line between parents and children and grandparents with grandchildren, and in the collateral line between full and half siblings (Art. 14). It could be seen that only the second degree of collateral line represents impediment, which is considered extremely narrow viewed comparatively. In theory, however, it is pointed out that although there is no formal restriction between the uncle/aunt and nephews and between children of full or half siblings, such cases are extremely rare in life. ${ }^{26}$ In Greece, an impediment exists in a direct line regardless of the degree, and in the collateral line to the fourth degree. ${ }^{27}$

In Hungary marriage is forbidden between relatives in direct line, between siblings, and between a person and the biological descendant of his/her sibling. ${ }^{28}$ However, in the latter case it is allowed for the notary to grant an exemption from the impediment to marriage before or after the marriage takes place. This is only allowed if the marriage will not "jeopardize the health of their children to be born as a result of such relation". ${ }^{29}$

Affinity is also a marriage impediment in Serbia, but much narrower than the blood and adoptive kinship. Marriage may not be concluded between in-law relatives in the first degree of direct line. These are: father-in-law and daughterin-law, son-in-law and mother-in-law, stepfather and stepdaughter and stepmother and stepson. The court may, for justified reasons, allow conclusion of marriage between in-law relations considering the marriage goals and family protection (art. 21 of Family Act and art. 82/5 of Act on Extra Civil Procedure). ${ }^{30}$

However, there are also legal systems in which relatives of the family can marry freely (for example Sweden, Finland, Germany, Russia, Slovenia, Croatia). ${ }^{31}$

${ }^{25}$ L. Tottie, 68. See Marriage (Prohibited degrees of relationship) Act 1986. Incest as a crime exists between a close circle of relatives, a man with a mother, a daughter, a granddaughter and a sister, and women with a father, son, grandson and brother. (John Dewar, Law and the Family, London, Dublin, Edinburgh, Butterworths, 1992. 46.)

${ }^{26}$ Семейный кодекс, art 14.

${ }^{27}$ E. Kounougeri-Manoledaki, 202.

28 Act V of 2013 on the Civil Code, Book IV, Section 4:12. https://www.ilo.org/dyn/natlex/ docs/ELECTRONIC/96512/114273/F-975134979/MK_13_031.pdf

${ }^{29}$ Ibidem

${ }^{30}$ Zakon o vanparničnom postupku (The Act on Extra Civil Procedure), Official Journal of the RS, No. 25/82, 48/88, 46/95.

${ }^{31}$ In Finland, affinity has been abandoned as an impediment by the 1987 Act. Bradley, op. cit., p. 298; in Germany from 1998. Marriage Act. (Rainer Frank, Parentage Law Reformed, The International Survey of Family Law, A. Bainham (ed.), The Hague, Boston, London, Martinus Nijhoff Publishers, 1997, 177.) 
"Only two of the member States (Italy and San Marino) reviewed had introduced such an impediment to marriage, and even then, that impediment was not absolute. The Court attached particular importance to this European consensus". ${ }^{32}$

If prescribed as an impediment, affinity prevents narrower circle of relatives to conclude marriage. Usually only marriage between affinal kins within first degree of the direct line is prohibited. There are also examples of affinity being considered as an impediment only in certain situations, for example if the ex-spouse is still alive (UK, 1986 amendments), or an impediment exists in the direct line, but dispensation can be obtained if there are important reasons and if the previous marriage ended in death (France). ${ }^{33}$

In the situation where the ex-spouse is no longer alive, the pre-existing relationships lose their significance. In the United Kingdom, a marriage shall not be void for reasons of affinity, if "both the parties have attained the age of twenty-one at the time of the marriage and the younger party has not at any time before attaining the age of eighteen been a child of the family in relation to the other party." ${ }^{34}$ This condition also protects family relationships, which are certainly firmer if there was previously a cohabitation between the parties in roles that were similar to parental (stepfather, stepmother and stepchildren). Greek law, however, attaches great importance to affinity even today (affinity is an impediment in a direct line, regardless of degree, and in collateral to third degree). ${ }^{35}$

Recently, the European Court of Human Rights decided in favor of the applicants, Greek nationalities, whose marriage was declared not valid in Greece on the fact that the wife was former sister in law of the husband.

"In today's Chamber judgmentl in the case of Theodorou and Tsotsorou v. Greece (application no. 57854/15) the European Court of Human Rights held, unanimously, that there had been: a violation of Article 12 (right to marry) of the European Convention on Human Rights. The case concerned a judicial decision annulling the marriage of Ms. Tsotsorou and Mr. Theodorou on the grounds that Ms. Tsotsorou was Mr. Theodorou's former sister-in-law. On the basis of Article 1357 of the Civil Code - which prohibits, in particular, marriage between persons of collateral affinity up to the third degree -, the Greek courts annulled the applicants' marriage, 10 years after it had been entered into, and held that the individuals in question were related in collateral affinity to the second degree. The Court found that the annulment of the applicants' marriage had disproportionately restricted their right to marry to such an extent that the very essence of that right had been impaired." 36

\footnotetext{
${ }^{32}$ https://www.echr.coe.int/Pages/home.aspx?p=caselaw/HUDOC\&c= visited 11102019.

${ }^{33}$ See art. $161-164$ of French Civil Code.

${ }^{34}$ Article 1 of Marriage (Prohibited Degrees of Relationship) Act 1986. http://www.legislation. gov.uk/ukpga/1986/16

${ }^{35}$ E. Kounougeri-Manoledaki, 202.

${ }^{36}$ ECHR 303 (2019) 05.09.2019 https://www.echr.coe.int/Pages/home.aspx?p=caselaw/HUDOC\&c $=$ visited 11102019 .
} 
Guardianship is a marriage impediment because it is a relationship which is incompatible with marriage. The guardian has a duty to take care of the ward, and his rights and duties are comparable to the parental rights and duties. The guardianship is a relationship that may be revoked, so if the guardian and the ward wish to marry, guardianship shall be revoked and marriage can then be concluded (art. 22 of Family Act).

\section{MARRIAGE FORM}

There are several systems related to the form of marriage. One is the system of compulsory civil marriage, which does not exclude the possibility of religious marriage. Civil marriage is now mandatory in a number of countries (Germany, France, Belgium, the Netherlands, Switzerland ${ }^{37}$, Russia, Serbia, etc.).

Second system is a system of dualism, that is, of equal status of civil and religious form of marriage, so that future spouses opt for one form or another, alternatively. System of dualism has also been accepted in a number of countries: in the UK, Scandinavian countries, Greece, US, Australia. In these countries religious marriage ceremonies are very common (in the UK over $2 / 3$ of the first marriages were concluded in religious form). System of dualism has also been introduced in some of the Eastern European countries.

Thus, in the Czech Republic, religious marriage ceremony is permitted by the 1992 Act (No. 234). It is similar in Poland, according to the Concordat with the Vatican. Although religious marriage was allowed in Poland before 1989, according to the Supreme Court's view, such a form did not produce any legal effects. The 1998 Family Act introduced a religious form in Croatia as an alternative to the civil form. Compulsory religious marriage is a form that has mostly historical significance, but in Israel, for example, it is still a mandatory form of marriage.

In Serbia, civil marriage has been mandatory since the adoption of the rules after the Second World War - Yugoslav Principle Marriage Act 1946. In Vojvodina, the civil marriage was mandatory much earlier, because the Hungarian law was in force before the Second World War (Marriage Act 1894, Para 29/1) which required mandatory civil marriage. The civil form of marriage, as mandatory, consists of a premarital procedure, ceremony of solemnization of marriage and registration of marriage. The authority for solemnization of marriage has registrar. ${ }^{38}$ If the marriage is to be solemnized between the citizens of Serbia staying

${ }^{37}$ In Switzerland, after the debate in the Parliament, as part of the 1998 amendments, the ban on religious marriage before a civil one was maintained. O. Guillod, 359 (new section 97/3 of the Civil Code corresponding to section 118/2).

${ }^{38}$ Until the amendments of the previous Act on Marriage and Family Relations 1993 (Закон о браку и породичним односима), the president or the representative of the Municipal Assembly 
abroad, the marriage may be solemnized before the diplomatic-consular officer. The premarital formalities include request of the spouses to get married, registrar's duty to check whether the requirements for marriage validity are met, and setting the date when the marriage will be solemnized. After that, the registrar will talk to the future spouses, with no public present, and inform them of the legal consequences of marriage. In addition to that, the registrar will recommend to the future spouses to inform one another about their health condition, and to visit appropriate medical institution, in order to obtain full information about all the data that are relevant for their health, diagnosis and prediction of diseases, medical treatment and results of treatment. The registrar will recommend to the future spouses to inform themselves of the possibilities and advantages of family planning, to visit marriage or family counseling service, to learn about the importance of maintaining a harmonious marriage and family relations and to agree on the last name (art. 292-304 of Family Act).

The act of solemnization of marriage is public, ceremonial and is usually conducted in a room designated for that purpose, (art. 299/1 of Family Act). The place has to be decorated to look ceremonial and the dignity of the act of solemnization has to be respected. Exceptionally, it may be allowed for the marriage to be solemnized at some other place, if there are especially justified reasons for that. In practice this solution is often used, so that the marriages are solemnized in private premises (at home) or public premises (hotels, restaurants). Exceptionally, marriage may be solemnized in the presence of one future spouse and proxy of the other future spouse if there are particularly justified reasons for that. Future spouses, two witnesses and the registrar shall be present during the solemnization of marriage. All the persons who have legal capacity may be witnesses. During the act of solemnization, the registrar informs the future spouses about the marital rights and duties, and after that the future spouses give the affirmative marriage statements. The act which follows is registration of marriage, i.e. documenting the marriage in the marriage register, (art. 301-303 of Family Act).

Nowadays, there is a widely accepted custom in Serbia to conclude marriage in a religious form apart from the civil one. According to the Marriage Rules of the Serbian Orthodox Church, which is the most widely accepted religion in Serbia, the marriage is defined as "... a holy sacrament in which two persons of the opposite sex attach themselves to one another, in the way prescribed by the Church through a spiritual and physical relationship, for the purpose of complete cohabitation and upbringing of children".

One of the distinctions between the civil, contemporary definition of marriage and the definitions of marriage according to the religious law is the element

was a competent authority, while the registrar was supportive authority. The competence was therefore transferred from the elected representative to the professional officer. 
of life-time duration of marriage. In other words, the Family Act has excluded the element of duration of marriage, although this does not imply, neither from the theoretical nor from the practical point of view, its shortness. The spouses today get married with the wish to have long and harmonious marriage, but if this cannot be achieved for some reason, they have an option to get a divorce. The other significant difference is that religious definitions view marriage as a sacrament (holy mystery). The principle of monogamy as a basic rule in marriage relations is prescribed both in civil and religious law.

\section{SOCIAL ASPECTS OF MARRIAGE}

Today in Serbia marriage rate is about five on 1000 population. It decreased from 7,5 thirty years ago. Approximately every forth marriage ends in a divorce in 2011 and every third in 2018 in Vojvodina. However, there is a difference comparing divorce rate in Serbia and Vojvodina thirty years ago. In Serbia app. every seventh marriage ended in a divorce at that time, thus in Vojvodina, every fifth marriage ended in a divorce. It could be noticed that the in Serbia during the period of thirty years divorce rate increased much faster than in Vojvodina.

Table 1

\begin{tabular}{|l|c|c|c|c|c|c|c|c|c|c|c|c|c|c|}
\hline & \multicolumn{4}{|c|}{ Marriage rate (1.000 population) } & \multicolumn{5}{c|}{ Divorce rate (1.000 population) } \\
\hline \multirow{2}{*}{ Year } & 19 & 19 & 20 & 20 & 20 & 20 & 20 & 19 & 19 & 20 & 20 & 20 & 20 & 20 \\
& 81 & 90 & 00 & 06 & 11 & 17 & 18 & 81 & 90 & 00 & 06 & 11 & 17 & 18 \\
\hline Serbia & 7,5 & 6,2 & 5,5 & 5,4 & 5 & 5,1 & 5,2 & 1,0 & 1,1 & 0,8 & 1,2 & 1,3 & 1,3 & 1,4 \\
\hline Vojvodina & 7,6 & 6,0 & 5,9 & 5,2 & 4,9 & 5,4 & 5,5 & 1,6 & 1,3 & 1,1 & 1,1 & 1,1 & 1,7 & 1,8 \\
\hline
\end{tabular}

Table 2

\begin{tabular}{|c|l|c|c|c|c|c|c|c|}
\hline & & \multicolumn{7}{|c|}{ Divorces (number on 1.000 marriages) } \\
\hline $\mathbf{1}$ & Year & 1981 & 1991 & 2002 & 2006 & 2011 & 2017 & 2018 \\
\hline $\mathbf{2}$ & Serbia & 141 & 145 & 238 & 206 & 230 & 257 & 275 \\
\hline $\mathbf{3}$ & Vojvodina & 213 & 223 & 227 & 232 & 252 & 320 & 319 \\
\hline
\end{tabular}

The marital structure of urban and other settlements is not the same. The biggest difference is the percentage of divorced persons, which is almost double in urban settlements. ${ }^{39}$ Today, the divorce is more frequent in urban, then rural population. In urban population is app. six percent of population over 15 years of

${ }^{39}$ Popis stanovništva, domaćinstava i stanova 2011. u Republici Srbiji - Populacija Srbije početkom 21. veka, Urednik Vladimir Nikitović, Beograd, 2015. 206. (Census of Population, Households and Dwellings 2011 in the Republic of Serbia, Serbia Population at the Beginning of the 21st Century, Ed Vladimir Nikitovic, Belgrade 2015), http://publikacije.stat.gov.rs/G2015/Pdf/G20154006.pdf 
age divorced, but in rural is almost four percent. ${ }^{40}$ This might be associated with the fact that the rural population kept the more patriarchal model of the family relations and with a younger age structure and less traditional marital behavior in urban areas. In urban areas, there is a higher percentage of unmarried and divorced persons, and a smaller proportion of married persons and widowers.

Table 3. Marital structure of the population aged 15 and over by type of settlement, by region, 2002 and 2011 censuses (\%)

\begin{tabular}{|l|c|c|c|c|}
\hline \multirow{2}{*}{$\begin{array}{l}\text { Marriage status of } \\
\text { population* }\end{array}$} & \multicolumn{2}{|c|}{ Republic of Serbia } & \multicolumn{2}{c|}{ Vojvodina } \\
\cline { 2 - 5 } & 2002 & 2011 & 2002 & 2011 \\
\hline Urban settlements & \multicolumn{2}{|l|}{} & \multicolumn{2}{|c|}{} \\
\hline Single & 26,7 & 29,6 & 28,6 & 31,8 \\
\hline Married & 58,6 & 53,8 & 55,5 & 51,1 \\
\hline Widows/widowers & 9,6 & 10,5 & 9,8 & 10,4 \\
\hline Divorced & 5,1 & 6 & 6,1 & 6,6 \\
\hline Rural settlements & \multicolumn{4}{|l}{} \\
\hline Single & 21,6 & 25,7 & 24,2 & 28,7 \\
\hline Married & 63,3 & 57,5 & 60,2 & 54,2 \\
\hline Widows/widowers & 12,5 & 13,4 & 12,4 & 13 \\
\hline Divorced & 2,6 & 3,4 & 3,2 & 4,1 \\
\hline
\end{tabular}

\section{REFERENCES}

Bradley David, "Politics, Culture and Family Law in Finland: Comparative Approaches to the Institution of Marriage", International Journal of Law, Policy and the Family, 12, 1998.

Dewar John, Law and the Family, London, Dublin, Edinburgh, Butterworths, 1992.

Draškić Marija, "Transsexual persons: Right to marry in the countries of former Yugoslavia", in Marriage and Quasi-marital Relationships in Central and Eastern Europe, (Edited by Lynn D. Wardle and A. Scott Loveless), BYU Academic Publishing, Provo, USA, 2008.

Draškić Marija, Transseksualitet i brak, Nomos, Beograd, 1994.

Glendon Mary Ann, The Transformation of Family Law, University of Chicago Press, 1996.

Guillod Olivier, “A New Divorce Law for the New Millennium”, The International Survey of Family Law, (ed. A. Bainham), Jordan Publishing, 2000.

${ }^{40}$ Stanovništvo: popis stanovništva, domaćinstava i stanova u 2002., Stanovništo, 12, Republički zavod za statistiku, Beograd, 2003. (The census of Population, Households and Dwellings 2002, Population, 12, Republic Statistics Authority, Belgrade 2003.) 
Guillod Olivier, "Choosing its Own Way or Following Others?", The International Survey of Family Law, (ed. A. Bainham), The Hague, Boston, London, Martinus Nijhoff Publishers, 1995.

Hamilton Caroline, Kate Standley, "Family Law in England and Wales", Family Law in Europe, Butterworths, Londos, Dublin, Edimburgh, 1995.

Kounougeri-Manoledaki Efie, "Family Law in Greece", Family Law in Europe, 1995.

Piškulić Zvonimir, Imre Đerđ, Osnovi privatnog prava u Vojvodini, Geca Kon, Belgrade, 1924.

Frank Rainer, "Parentage Law Reformed", The International Survey of Family Law, (ed. A. Bainham), The Hague, Boston, London, Martinus Nijhoff Publishers, 1997.

Schrama M. Wendy, "Registered Partnership in the Netherlands", International Journal of Law, Policy and the Family, 13, 1999.

Tottie Lars, "Family Law", An Introduction to Swedish Law, (ed. Stig Strömholm), Springer, Dordrech, 1981.

Popis stanovništva, domaćinstava i stanova 2011. u Republici Srbiji - Populacija Srbije početkom 21. veka, Urednik Vladimir Nikitović, Beograd, 2015.

Stanovništvo: popis stanovništva, domaćinstava i stanova u 2002., Stanovništo, 12, Republički zavod za statistiku, Beograd, 2003.

Bračna pravila Srpske pravoslavne crkve, II dopunjeno i ispravljeno izdanje Svetog arhijerejskog sinoda, Beograd 1994.

Family Code of Albania, Law Number 9062 Adopted May 8, 2003.

Marriage (Prohibited Degrees of Relationship) Act 1986. http://www.legislation.gov. uk/ukpga/1986/16

Marriage Act of Sweden (SFS 1987:230, with amendments 1988:1452), https://www. riksdagen.se/sv/dokument-lagar/dokument/svensk-forfattningssamling/aktenskapsbalk-1987230 sfs-1987-230

Obiteljski zakon, NN STužbeni list Republike Hrvatske, Br. 103/15, 98/19.

Porodični zakon, Službeni glasnik Republike Srbije, br. 18/05.

Odluka Ustavnog suda Republike Srbije: UŽ-3238/2011 http://www.ustavni.sud.rs/ Storage/Global/Documents/UstavneZalbe/\%D0\%A3\%D0\%B6-3238-2011.pdf

Zakon o izmenama i dopunama zakona o matičnim knjigama, Službeni glasnik RS, br. $47 / 2018$.

Zakon o vanparničnom postupku, Službeni glasnik Republike Srbije, Br. 25/82, 48/88, 46/95.

Семейный кодекс и брачный договор, Сощчиальная защчита, выпуск 5/1996. 
Др Горяана Б. Ковачек Сйанић, реgовни йрофесор

Универзииетеи у Новом Саgу

Правни факулиетеи у Новом Саgу

G.KovacekStanic@pf.uns.ac.rs

Др Саняра О. Самариић, асисиетенй са докӣораӣом

Универзииетеи у Новом Саgу

Правни факулиетет у Новом Саgу

Sandra.Samardzic@pf.uns.ac.rs

\section{Брак у српском и упоредном праву}

Сажейак: Према Породичном закону Србије, брак је законом уређена

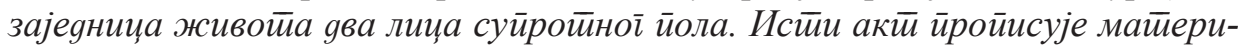
јалне и формалне услове за закључење брака. Овај рая има за циљь gа иружи иррейле ових услова у домаћем и уйореgном йраву. Сваки ов услова анализиран је засебно, gатии су йреїлеgи њиховоі истиоријскоі развоја и начина на који су они gанас реїулисани у различийим иравним системемма. Према йозийивном

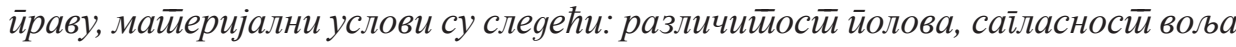

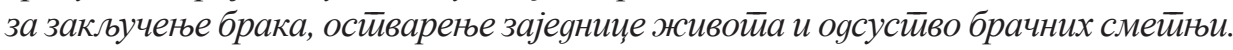
Међутиим, у савременом йородичном ирраву йоситоји ииенденција gа се реgукује

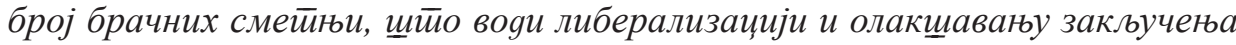
брака. Буяући яа се брак врло честио закључује у верској форми, рая йакође gаје йрейлеg ирквених ирравила која се йичу брака. Коначно, анализирају се и уйоређују сииаииистички иоодачи о броју закључених бракова и о броју развоgа

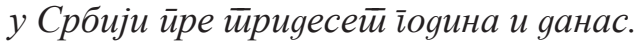

Кључне речи: брак, услови за закључење брака, форма брака, брачне сметиње, развоg.

Датум пријема рада: 14.01.2020. 